\title{
Una mirada crítica sobre el "Uruguay excepcional". Reflexiones para una historia de larga duración sobre la violencia estatal en el siglo XX
}

Magdalena Broquetas

Universidad de la República, Uruguay.

magdalena.broquetas@gmail.com

\author{
Nicolás Duffau \\ Universidad de la República, Uruguay. \\ nicolasduffausoto@gmail.com
}

Artículo recibido: 03 de junio de 2019. Aprobación final: 12 de diciembre de 2019.

\section{Resumen}

La historia política uruguaya del siglo XX se caracterizó por la negociación, los acuerdos inter e intrapartidarios y el escaso protagonismo de las Fuerzas Armadas hasta el golpe de 1973. Sin embargo, en las últimas décadas el lugar común que descansa en la idea del "Uruguay excepcional" ha obstaculizado comprender con perspectiva histórica lo ocurrido en la última dictadura civil militar, atravesada por el terrorismo de Estado. Han sido muy escasos los estudios que se plantean la perdurabilidad de prácticas represivas y conductas autoritarias, así como las comparaciones o esfuerzos de síntesis que comprendan a los distintos episodios de ruptura democrática del siglo XX.

Al establecer una mirada de larga duración sobre las modalidades y la intensidad de la violencia estatal en el siglo XX, este artículo propone identificar y sistematizar las características y los instrumentos de la represión estatal focalizada en la disidencia política, con el objetivo de abrir la reflexión, proponer claves de análisis y establecer futuros cauces de investigación sobre las formas de continuidad del autoritarismo en el Uruguay del siglo XX. 


\title{
A Critical Review of the Uruguay's "Exceptionality". Reflections for a Long-run History about State Violence in the 20th Century
}

\begin{abstract}
Negotiations among and within political parties characterized twentieth-century Uruguayan political history, with only a limited role of the Armed Forces until the 1973 coup. This alleged 'exceptionality' has hindered the historical understanding of the last military-civil dictatorship and state-sponsored terrorism. Few studies consider the durability of repressive and authoritarian practices. Similarly, there is a scarcity of comparisons and synthesis including the different episodes of the breaking of democracy. By bringing a long-term perspective on the modalities and intensity of state violence in Uruguay during the last century, this article identifies and systematizes both the characteristics and instruments of state repression against political dissents. With the goal of generating reflection, this article offers analytical key aspects for a future research agenda on the continuity of authoritarianism in the country.
\end{abstract}

Keywords: State Violence - Uruguay - 20th Century

\section{Introducción ${ }^{1}$}

El 27 de junio de 1973 el presidente de Uruguay,Juan María Bordaberry, decretó la disolución del Parlamento, dando inicio a una dictadura liderada por una coalición de civiles y militares, que mantuvo el control del Estado hasta el 1 de marzo de 1985. Era la tercera vez en el siglo XX que en un presidente electo constitucionalmente daba un golpe institucional. En este caso lo original fue la participación protagónica de las Fuerzas Armadas y su involucramiento en la represión de la oposición política y social, que alcanzó niveles e intensidades hasta entonces desconocidos. Durante la última dictadura el Estado actuó sin los controles que rigen en la vida democrática. La modalidad represiva más extendida fue la prisión masiva y prolongada de opositores de la izquierda política (partidaria y armada), sindical y social. Aproximadamente seis mil personas fueron procesadas por la Justicia Militar, carente de independencia e imparcialidad, a lo que debe sumarse una cifra similar de detenidos sin ningún tipo de proceso. ${ }^{2}$ En 1976 Uruguay tenía el índice más alto de América del Sur de presos políticos en relación al total de su población. En los centros de detención -legales y clandestinos- de todo el país la tortura se transformó en una práctica rutinaria. La represión estuvo a cargo de las tres ramas de las Fuerzas Armadas y la Policía que, de manera planificada y coordinada, se ocuparon tanto del seguimiento y la vigilancia, como de la custodia de los detenidos por motivos políticos. En su actividad represiva las fuerzas de

1 Agradecemos muy especialmente a Pascual Muñoz y Rodolfo Porrini las sugerencias bibliográficas y documentales realizadas.

2 La cifra comprende a los detenidos o procesados por la justicia militar desde el año 1972. (Investigación Histórica sobre la dictadura y el terrorismo de Estado en Uruguay. 1973-1985, 2008, tomo II: 66) 
seguridad desconocieron las fronteras nacionales, siendo usual la coordinación con los gobiernos de la región con los cuales existía afinidad ideológica y política. Más de 170 uruguayos detenidos durante la dictadura permanecen desaparecidos. Capturados en su mayoría en Uruguay y Argentina -aunque también se dieron detenciones ilegales en otros países americanos-, algunos de ellos fueron vistos por última vez en centros clandestinos de detención y otros fueron trasladados ilegalmente a Uruguay. Entre los detenidos desaparecidos hubo niños secuestrados con sus padres y nacidos en cautiverio (Rico, 2008, t. I). Además de la prisión, la represión se caracterizó por el extremo control social y la expulsión de parte de la población. La sociedad en su conjunto fue controlada a través de decretos y actos institucionales que limitaron de manera muy eficaz derechos políticos y laborales. Miles de uruguayos partieron al exilio por diferentes vías, engrosando los contingentes de emigrantes que desde comienzos de la década de 1960 dejaban el país como consecuencia de la crisis económica (Dutrénit Bielous, 2006).

El golpe de Estado de 1973 no fue un acontecimiento repentino e inesperado, sino el desenlace de un largo proceso de deterioro del régimen democrático, claramente reconocible a partir de 1968, pero cuyas raíces más profundas deben ubicarse en la crisis económica de mediados de la década de 1950 y la conflictividad social derivada de esta situación. Los estudios que abordan el ascenso del autoritarismo en la década de 1960 y las causas que condujeron a la dictadura coinciden en la valoración del año 1968 como punto de inflexión en la violencia política ejercida descle el Estado (Rial, 1984, vols. I y II; Varela, 1988; Demasi, 2001). Entre agosto y setiembre de ese año, en una situación sin precedentes en la historia uruguaya, tres estudiantes que participaban en manifestaciones en repudio al autoritarismo y los recortes presupuestarios en la enseñanza perdieron la vida a causa de las heridas provocadas por balas policiales. Ese fue el preludio de un lustro matrizado por la represión a la protesta de calle, la masificación de los arrestos y detenciones arbitrarias y la generalización de la tortura.

Álvaro Rico (2003: 2, 3) ha sostenido que este fue el inicio del "camino democrático al autoritarismo”, expresión que generó amplio consenso académico y que alude a la sistemática represión gubernamental de la conflictividad social y política a través del empleo de la fuerza y la adopción reiterada de una serie de instrumentos legales que suspendían derechos y libertades en supuesta defensa de la seguridad nacional. La mutación del Estado de derecho en Estado policial y, a partir de 1972, en Estado terrorista, comprende el lustro previo a la ruptura institucional (Rico, 1989). Sobre la base de estas nociones se ha discutido acerca de la periodización, los protagonistas y las causas de la crisis y el autoritarismo (Marchesi y Markarian, 2012: 213-243; Rilla, 2015:218-241). Sin embargo, han sido muy escasos los estudios que se plantean la perdurabilidad de prácticas represivas y conductas autoritarias, así como las comparaciones o esfuerzos de síntesis que comprendan a los distintos episodios de ruptura democrática del siglo XX (Rial, 1984, vol. I: 97-145; Cuadro, 2010: 341-348; Kierszenbaum, 2012).

Una década atrás algunos trabajos señalaron la existencia de un hiato en la narrativa histórica que, por un lado, hacía énfasis en el "decenio glorioso", comprendido 
entre la inmediata segunda posguerra y el inicio de la crisis económica en 1958 (coincidente con la victoria de una coalición de derechas) y, por otro, señalaba la virulencia de la crisis política y social que marcó al lustro anterior al golpe de 1973 (Broquetas, 2014; Espeche, 2016). En ellos se partía de la constatación de que, tanto en el imaginario colectivo como en la literatura histórica (fundamentalmente politológica, sociológica y ensayística), la crisis de los años sesenta, y más específicamente de la segunda mitad de la década, suponía un parteaguas en el devenir del siglo XX. Hasta ese momento el relato histórico omitía o minimizaba cualquier rasgo de violencia estatal. De acuerdo a esta extendida percepción, Uruguay había experimentado otros golpes de Estado, pero se trataba de episodios "insignificantes" si se los comparaba con los de los países vecinos, había sido muy poca la sangre derramada y prácticamente no existían conflictos étnicoraciales. Por el contrario, se enfatizaba en la permanencia de una conformación social poco proclive a los cambios bruscos, amortiguadora de conflictos, con un estable sistema de partidos políticos, que actuaban como eficientes intermediarios de las demandas de distintos sectores ante un Estado que se caracterizaba por anticiparse a los grandes conflictos sociales a través de la intervención y la regulación de aspectos básicos de la vida pública. En el relato y en el imaginario, este Uruguay pacífico y de medianías entró en crisis hacia fines de los sesenta, cuando la protesta social (partidaria, sindical, estudiantil, guerrillera) adquirió una magnitud desconocida, al igual que la respuesta represiva (D’Elía, 1982; Real de Azúa, 1984; Rama, 1987). ${ }^{3}$

Quienes llamaban la atención sobre esta grieta entre los dos modelos explicativos advertían que el lugar común del "Uruguay excepcional” había obstaculizado comprender con perspectiva histórica la crisis y la dictadura y demandaban investigaciones específicas para el período comprendido entre 1958 y 1968, movilizados por la presunción de que en ese lapso se había gestado buena parte de las prácticas y de los imaginarios que irrumpieron con virulencia a partir del 68. En otras palabras: parecía evidente que la propensión autoritaria del elenco político que tenía a su cargo la conducción del Estado no había nacido repentinamente y urgía conocer más y mejor el mal llamado período de los "colegiados blancos" (1959-1967) y del breve gobierno de Oscar Gestido (1967).

Este cambio de óptica, acompañado de esfuerzos de acumulación de evidencia empírica, contribuyó a revisar la periodización laudada para los años sesenta y arrojó numerosos indicios que permitieron retrotraer la criminalización de la protesta social y la propensión autoritaria por parte del gobierno a los primeros años de la década de 1960 (Bruno, 2007; Bucheli, 2012; Broquetas, 2014). Quedó demostrada la participación en este proceso de actores políticos y sociales que permanecían ausentes o muy superficialmente visibilizados (Partido Nacional, Fuerzas Armadas, Policía, asociaciones gremiales patronales, asociaciones gremiales rurales, sectores de la Iglesia Católica), así como la dimensión regional y transnacional de los principales fenómenos económicos, políticos, sociales y

3 Una perspectiva disidente, que apunta a deconstruir la noción de "estado de bienestar" y evidenciar la trama clientelar del Estado uruguayo en los años cincuenta, es la de Ana Frega (1993: 91-103). 
culturales. En suma, esta revisión permitió reelaborar una periodización en la que el giro autoritario se muestra menos abrupto, en relación directa con la percepción de amenaza de las derechas (inspirada en tanto en la realidad uruguaya como en la latinoamericana y mundial) y menos asociado a actores individuales que a un heterogéneo conglomerado de grupos sociales, que apenas coincidía en lo que rechazaba. Este nuevo marco explicativo permitió descartar la idea del paréntesis de la primera mitad de la década de 1960, y a la vez abrió cauces que nuevamente invitan a repensar los procesos represivos en términos de temporalidad, representatividad y vigencia de ciertas matrices ideológicas y hábitos en los comportamientos del Estado.

La magnitud de la represión y la violencia tanto estatal como para-estatal,implementada a partir de un basamento legal, una serie de prácticas de vigilancia, control y coerción y la circulación de estereotipos estigmatizantes, todos ellos de larga data, amerita -e incluso demanda- abordajes que trasciendan la coyuntura identificada con la radicalización de los conflictos de la Guerra Fría y sustituyan la consideración de lo inusual, lo nuevo o lo inédito por otra, que identifique permanencias y se proponga reponer el arraigo histórico y la perdurabilidad de prácticas y discursos, por lo general cristalizadas en el período en que cobraron mayor notoriedad.

La reconstrucción de la genealogía de la represión estatal en el Uruguay del siglo $\mathrm{XX}$ excede las posibilidades de este texto y requeriría otro respaldo empírico. Con pretensiones más modestas, partiendo de la falta de conexión existente en los esfuerzos históricos explicativos entre el período del autoritarismo y la dictadura y otros momentos del siglo XX, este artículo apunta a persuadir sobre la conveniencia de adoptar una mirada de larga duración en relación a las modalidades y la intensidad de la violencia estatal en el siglo XX. Esto último supone desarticular y revisar la noción de "excepcionalidad" tanto en sus connotaciones negativas como positivas, dejando de lado la idea de que el tipo de violencia estatal de la última dictadura fue algo "raro", que se apartó de la "normalidad", lo cual impide reconocer la historicidad y el sentido de ciertas lógicas, pero también poniendo en cuestión la supuesta excepcionalidad democrática, que hace las veces de signo identitario del Uruguay dentro y fuera de fronteras. Esta reflexión sobre el arraigo histórico y las continuidades en la represión estatal promueve, además, considerar esta cuestión en términos no estrictamente nacionales sino en diálogo con lo ocurrido en otros países de la región.

El artículo propone una mirada diacrónica desde fines del siglo XIX hasta la ruptura institucional de 1973, organizada en torno a tres períodos. El primero comprende el tramo cronológico en que estuvo vigente el primer Código Penal (1889-1933) y la creación de los cimientos de los servicios de vigilancia política. El segundo período comienza con la dictadura iniciada con el golpe de 1933 y comprende hasta el final de la Segunda Guerra Mundial, años durante los cuales se discutieron y aprobaron leyes restrictivas de las garantías individuales que permitieron criminalizar la protesta política y social. El tercer tramo cronológico coincide con la radicalización de los conflictos sociales en clave de Guerra Fría y con una mayor virulencia en la represión estatal. En cada coyuntura se 
identifican las características de la represión por parte del Estado (instrumentos, modalidades, agentes), así como sus niveles de intensidad y los grupos sociales especialmente perjudicados. En suma, el texto ofrece un panorama sintético de larga duración sobre la represión estatal en Uruguay, que refleje la magnitud y las diversas escalas de violencia política reconocible entre fines del siglo XIX y la ruptura democrática de 1973.Se busca, en primer lugar, dejar planteada la pertinencia de un abordaje cronológico más amplio que el que suele emplearse para analizar el fenómeno de autoritarismo en ascenso en el marco de la Guerra Fría. En segundo lugar, aspiramos a identificar líneas y claves para el análisis de este fenómeno, que deberán ser retomadas en investigaciones de más largo aliento.

\section{Agitación sindical, consolidación estatal y modernización de los servicios de vigilancia y represión (1889-1933)}

Desde el último cuarto del XIX y, en particular, en los inicios del XX el incipiente proceso de industrialización propició la expansión del universo de trabajadores asalariados y con ellos la proliferación de organizaciones sindicales, que canalizaron sus reivindicaciones mediante acciones colectivas, en ocasiones de carácter violento. La respuesta gubernamental ante la protesta sindical solía ser de índole represiva y decididamente favorable a los intereses patronales. Eran usuales las denuncias del Ministerio Público contra militantes sindicales y la aplicación del Código Penal de 1889 en los artículos relativos a los "delitos contra la seguridad del Estado", entre los que se encontraban los de "rebelión", "sedición”, "motín” y "asonada", "asociaciones ilícitas" y otras formas de "atentar contra el orden social, la moralidad o las propiedades” (República Oriental del Uruguay, 1889: 36-41).

Al mismo tiempo, son numerosos los testimonios que dan cuenta de la represión policial para enfrentar las huelgas y otras medidas de resistencia gremial, entre las que figuraban piquetes, boicots, sabotajes o difusión de folletería y publicaciones obreras (Zubillaga, 1997: 88-98). Lejos de entender la acción sindical en términos de reivindicación salarial y como reflejo de las malas condiciones de vida de los sectores trabajadores, la interpretación hegemónica de la conflictividad sindical remitía a la idea de alteración del orden público, lo cual justificaba su criminalización. Además de la represión física a cargo de las fuerzas policiales, que solía dejar como saldo trabajadores heridos, durante este período se reorganizaron los sistemas estatales de vigilancia y control social, originalmente concebidos para la vigilancia preventiva de la población marginal -fundamentalmente prostitutas, delincuentes, vagos y enfermos psiquiátricos- y luego extendida a los llamados delincuentes sociales y agitadores obreros (Broquetas y Bruno, 2012: 176-198). Desde el último cuarto del siglo XIX las brigadas o divisiones de investigaciones o seguridad pusieron particular atención en la movilización sindical y las actividades de agitación social y cultural. Mediante la aprobación de nuevos reglamentos, la Policía fue profesionalizando las secciones de investigación (Victoria Rodríguez, J., 2008 tomo II: 137-139). Esta tendencia a la ampliación de los servicios de vigilancia estatal se acentuó a partir del magnicidio del presidente Juan Idiarte 
Borda, ocurrido el 25 de agosto de 1897. En simultáneo a este acontecimiento tuvieron lugar levantamientos armados, liderados por el caudillo nacionalista Aparicio Saravia y el gobierno decretó restricciones a la prensa y reglamentación del derecho de reunión (Barrán y Nahum, 1972).

Tras el asesinato de Idiarte Borda, Juan Lindolfo Cuestas, en ese entonces presidente del Senado, asumió la presidencia de la República. En febrero de 1898, debido a discrepancias en la interna del Partido Colorado, al que pertenecía el Presidente Cuestas, disolvió las cámaras y formó un Consejo de Estado, que se mantuvo en funciones durante un año (Caetano, 2016:45). En el primer año del gobierno tuvo lugar un motín militar que fue sofocado mediante el decreto de estado de sitio y el destierro de sus líderes. Otros intentos armados de la oposición o supuestas conspiraciones, fueron controlados y los líderes expulsados del país o destituidos en caso de ocupar cargos en la administración pública. Asimismo, la policía debió intervenir en numerosos conflictos obreros, llegando en 1901 a la clausura de locales y la disolución de reuniones sindicales (González Sierra, 1989: 9).

La solidaridad entre movimientos huelguísticos de ambas orillas del Río de la Plata se expresó en contribuciones monetarias, gestión de puestos de trabajo o lealtades a la hora de no suplir a trabajadores en conflictos. Desde fines del siglo XIX fueron varios los acuerdos de protección y colaboración A su vez, en 1902 se intentó organizar en Buenos Aires un congreso de trabajadores sudamericanos con el objetivo de planificar acciones concretas, pero también de estudiar la situación económica, social e intelectual del proletariado en la región (Zubillaga, 1997: 30-33).

Las policías de los países del Cono Sur latinoamericano respondieron al temprano relacionamiento transfronterizo de las organizaciones sindicales con diversas iniciativas de cooperación y coordinación para el intercambio de información (congresos sudamericanos, convenios en los que se establecieron categorías de individuos que serían objeto de intercambio), que en esta materia venían a complementar las fluidas comunicaciones a nivel de las cancillerías. Desde fines del siglo XIX, se instrumentaron variados mecanismos de identificación civil, que permitieron al Estado iniciar un paulatino proceso de control sobre la ciudadanía, a través de distintos registros (García Ferrari, 2010: 113-185; Fessler, 2015: 15-39). Las fichas personales, dactiloscópicas y fotográficas fueron utilizadas por el personal policial para la represión de los llamados "delitos comunes", pero también para conocer y controlar a militantes políticos y sociales. La preocupación policial fue complementada con el accionar de técnicos que trabajaban para el Estado (entre los que figuraban médicos y abogados), encargados de describir el comportamiento de los militantes políticos o sociales, en especial anarquistas, con una supuesta neutralidad científica que legitimaba el accionar institucional ante individuos que eran considerados como desestabilizantes del orden social (Duffau, 2019: 223-240).

José Batlle y Ordóñez asumió la presidencia el 1º de marzo de 1903 y durante los dos primeros años de mandato debió hacer frente a los levantamientos armados, 
nuevamente liderados por el caudillo nacionalista Aparicio Saravia, reclamando la coparticipación política, ${ }^{4}$ que finalizaron con la paz firmada el 24 de setiembre de 1904. En los meses que duró el conflicto el gobierno estableció prohibiciones a la prensa para informar sobre el curso de la guerra.

El gobierno de José Batlle y Ordóñez supuso un cambio en la actitud gubernamental hacia el movimiento sindical, al que se trató de neutralizar a través de la negociación y el arbitraje. Entre 1903 y 1915 -período que comprende las dos presidencias de Batlle y la de Claudio Williman- los respectivos gobiernos reconocieron derechos gremiales y mostraron cierta tolerancia hacia algunas manifestaciones obreras (Barrán y Nahum, 1983). Sin embargo, la Policía contó con numerosos informantes en organizaciones sociales, sindicatos y agrupaciones obreras, en especial de tendencia anarquista y tuvieron lugar varios episodios de represión violenta, como el ocurrido en 1905 en un contexto de huelgas en varios sectores que arrojó como saldo numerosos heridos y un sindicalista muerto. Otro momento de duros enfrentamientos con la policía del gobierno de Batlle tuvo lugar en mayo de 1911 cuando el paro de los empleados tranviarios derivó en la primera huelga general de la que participaron más de treinta sindicatos (Balbis y Zubillaga, 1985, vol. I: 104-107).

La puesta en marcha de una serie de reformas sociales y económicas que apuntaban a mejorar las condiciones de vida y trabajo de obreros y empleados provocó profundo malestar entre las clases altas y representantes del capital. Precisamente fueron estos sectores los que lograron desplazar del gobierno al batllismo más radical, percibido como "peor que el socialismo", y retomar el control del Estado sobre la base de una serie de pactos y compromisos que buscaban frenar los cambios más drásticos impulsados por el reformismo y contemplar los intereses de la derecha política y los sectores patronales (Barrán y Nahum, 1987; Caetano, 1992, tomo I; Broquetas, 2019: 157-188).

Hacia 1917, coincidiendo con el ingreso de Estados Unidos en la Primera Guerra Mundial, se vivió un proceso de desaceleración económica, aumento del costo de vida y caída del salario real, que alentó la multiplicación de los conflictos obreros. En simultáneo, la Revolución Rusa se transformaba en una referencia para fuerzas políticas y sociales de izquierda en todo el mundo. Este fue también un momento de fortalecimiento del movimiento sindical en Occidente. En Uruguay, neutralizado el sector más progresista del Partido Colorado, la tónica volvió a ser la represión al movimiento obrero. En 1918 asociaciones gremiales patronales y líderes políticos aplaudieron las acciones de la policía para desmantelar en Montevideo una huelga, que involucró entre otros a trabajadores portuarios, tranviarios y funcionarios públicos, y finalizó con heridos y tres muertos (Alonso Llera, Mario Rodríguez y Manuel Pereyra). ${ }^{5}$ Según denunció la prensa anarquista, divisiones del Ejército recorrieron las calles de la capital y se encargaron de la

4 José Pedró Barrán y Benjamín Nahum (1972) fueron pioneros en interpretar las "revoluciones" saravistas como conflictos con un origen político, pero también social.

5 (24 de agosto de 1918), Caras y Caretas, Buenos Aires. 
custodia de las usinas eléctricas. Los sectores empresariales amenazaron con un boicot patronal y confeccionaron listas negras (Caetano, 1992: 83-89; Muñoz, 2014).

Entre 1917 y 1919 el "miedo rojo", diseminado por todo el mundo, tuvo su expresión en Uruguay. José Pedro Barrán (2004: 103-117) demostró que el proclamado temor a la expansión de la Revolución Rusa escondía un miedo mucho más palpable ante sindicatos, movimientos anarquistas, socialistas y comunistas, cuya actuación era vista por los grupos empresarios y conservadores como la antesala de una posible insurrección social. Esto, no obstante, no se condecía con el peso real de la izquierda política, social y sindical, de magra representatividad electoral y escaso arraigo popular. El espectro político partidario de izquierda comprendía desde 1910 al Partido Socialista, del cual a partir de las disposiciones de la Tercera Internacional surgió en 1921 el Partido Comunista del Uruguay. Hasta mediados de la década de 1960 ambos concitaron una adhesión electoral cuasi testimonial. Más que en el Parlamento, su influencia se hizo sentir en el movimiento popular (sindical y estudiantil), lo cual fue percibido y reiteradamente señalado por la derecha política y las representaciones diplomáticas extranjeras con mayor presencia en Uruguay, entre las que figuraban las de Francia, Gran Bretaña y Estados Unidos (Albornoz y Galeano, 2017: 101-134; Díaz, 2019). Por fuera del sistema de partidos puede reconocerse la temprana presencia anarquista, que desde fines del siglo XIX incidía en las luchas obreras y desde los años veinte cobró mayor notoriedad a partir de las acciones del anarquismo expropiador, movilizado en ambas orillas del Río de la Plata. Al margen de la espectacularidad de sus acciones, los anarquistas de esta tendencia fueron rápidamente controlados y reprimidos.

Como ha demostrado Daniel Lvovich (2016: 21-39), la discusión sobre la inmigración al Río de la Plata durante la inmediata posguerra dejó en evidencia entre los gobernantes el peso del antisindicalismo, muy imbricado con un antisemitismo que justificó acciones de extrema violencia contra la población judía. En simultáneo a lo ocurrido durante la "Semana trágica" en Buenos Aires, en los primeros días de enero de 1919 el gobierno uruguayo responsabilizó a supuestos agitadores extranjeros de un intento de huelga general que, según se dijo públicamente, tenía por finalidad última organizar un soviet local. La movilización de regimientos militares en el barrio obrero del Cerro y el despliegue de fuerzas policiales impidieron la realización de una reunión de la Federación Obrera Regional del Uruguay (FORU). Varios trabajadores fueron detenidos y algunos de ellos deportados.

Este no era un fenómeno del todo novedoso, puesto que desde comienzos del siglo XX agrupaciones del Partido Nacional con representación parlamentaria exigían la aprobación de leyes similares a las de residencia promulgada en Argentina en 1902 y su complemento, la Ley de Defensa Social (1910), que permitían la expulsión de agitadores extranjeros. La discusión parlamentaria de iniciativas obreristas habilitó un espacio para el debate de proyectos de ley que proponían limitar el ingreso al país de elementos considerados perniciosos. Durante el período de entreguerras la inmigración presentó una modificación sustancial en su composición étnica a partir de la llegada de colectivos que no habían tenido una presencia significativa previa. Entre ellos se encontraban armenios, judíos de 
Europa Oriental, rusos y árabes, frente a los cuales se promovieron políticas de fiscalización y vigilancia (Martínez, 2013:53-56; Díaz, 2019:48-52). El crecimiento de la xenofobia y el antisemitismo no se puede entender si no es en relación con discursos regionales de preocupación por los extranjeros y de temor ante un proceso insurreccional (Aldrighi, 2000: 129-224). Los sectores más conservadores del gobierno alertaron acerca de la supuesta permisividad de las leyes uruguayas que habilitaban el ingreso indiscriminado de inmigrantes, entre los cuales se podrían encontrar militantes anarquistas, que arribaban al país para divulgar sus ideas y recurrir a la violencia como herramienta política.

En simultáneo, en la década de 1920 se iniciaron reformas administrativas en la Policía de Montevideo mediante una reestructura de las distintas reparticiones y la dotación de mejores recursos a las divisiones encargadas de la investigación de delitos vinculados al orden público, entre los que se encontraban los de carácter político. La sección de investigaciones de la Jefatura de Policía de Montevideo pasó a tener una Sección Orden Social y Leyes Especiales, encargada de "ejercer vigilancia y represión sobre todos los lugares, centros, reuniones, sociedades, etc., en donde se cometan, intenten o fragüen actos que atenten contra la moral, las buenas costumbres, y el orden establecido". La repartición tenía como función explícita la represión de los delitos de "sedición, motín y asonada" y de los "movimientos obreros, huelguísticos y políticos” (Armand Ugon et al., 1930: 137-187). Para entonces estaba muy consolidada la idea de que el "comunista" representaba un "otro" que promovía ideas políticas, sociales y hasta culturales radicalmente irreconciliables con el modo de vida de los uruguayos. Esta prédica esencialista, reconocible en gobernantes y formadores de opinión, se revitalizó en el contexto del cambio de década cuando el gobierno uruguayo definió la creación de un ente estatal que tendría el monopolio del combustible nacional (Administración Nacional de Combustible, Alcohol y Portland, ANCAP) y entabló vínculos comerciales con la Unión Soviética. Esto había sido posible en el marco de una institucionalidad que cobijaba sectores antagónicos en el seno del Poder Ejecutivo y se sostenía sobre la base de una compleja dinámica de pactos y acuerdos inter e intrapartidarios.

Los grupos de presión empresarial, la derecha política (sectores de los partidos Nacional, Colorado y de la católica Unión Cívica), y representantes diplomáticos de las principales potencias mundiales de Occidente desde hacía dos décadas se manifestaban en contra de la ampliación del monopolio comercial e industrial del Estado, denunciando a viva voz el filo-comunismo de proyectos que ponían en tela de juicio el derecho de propiedad y las virtudes de la iniciativa privada. La creación de ANCAP en 1931 reavivó el fantasma comunista, esta vez corporizado en la misma URSS, puesto que la ganadora de la licitación pública para la provisión de gasolina y querosene para el nuevo ente era una empresa petrolera estatal soviética. En suma, la reaparición de cierto espacio para nueva legislación social y estatista en un contexto local y regional atravesado por el problema migratorio y el afianzamiento de las relaciones comerciales entre Uruguay y la URSS ambientaron la primera campaña anticomunista del siglo XX (Caetano y Jacob, 1990: 111-129). 
El ascenso mundial de los fascismos y sus repercusiones antidemocráticas en la región son algunos de los factores que explican el giro a la derecha del gobierno de Gabriel Terra, un batllista heterodoxo que fue tejiendo una red de alianzas con sectores conservadores de los dos grandes partidos políticos, cuyo cometido principal era alejar definitivamente del gobierno a los grupos más radicales del batllismo. El año 1932 marcó un punto de inflexión en el anticomunismo estatal y la violencia generada en su nombre. En el mes de febrero, ante denuncias de representantes diplomáticos de la existencia de un plan subversivo encabezado por los comunistas de Uruguay, el presidente Terra adoptó una serie de medidas represivas que supusieron acuartelamiento de tropas, allanamiento de locales sindicales y domicilios particulares, clausura de las oficinas del diario comunista Justicia e intervención de la administración de correos y telégrafos. Se produjeron detenciones de políticos de izquierda y militantes sindicales, así como de integrantes del Partido Nacional que no estaban aliados con el gobierno. En el correr de los días siguientes fueron continuos los patrullajes policiales y militares. Por primera vez las tres centrales sindicales y sindicatos autónomos lograron sortear sus divisiones para convocar a un paro conjunto acompañado por la Federación de Estudiantes Universitarios, que redundó en varios días pautados por incidentes y detenciones. Algunos contemporáneos advirtieron con preocupación sobre el carácter desmedido de la represión policial, el brote xenófobo y la recepción social relativamente pasiva de esta escalada represiva. En proyección, el "complot comunista” de febrero de 1932 ambientó el inicio de una sostenida prédica golpista.

El presidente declaró públicamente que se estaba ante una "inminente conmoción extremista" (Victoria Rodríguez, 2008, tomo III: 84), lo cual justificaba la adopción de medidas prontas de seguridad, ratificadas por mayoría legislativa los días siguientes. La figura de las medidas prontas estaba en la Constitución descle el texto de 1830, previéndose su implantación en "casos graves e imprevistos de ataque exterior o conmoción interior". ${ }^{6}$ En adelante y hasta el presente, las medidas prontas de seguridad mantuvieron su vigencia en los mismos términos en las sucesivas reformas constitucionales (correspondientes a los años 1919, 1934, 1951 y 1966).

\section{Represión física y legal en la creación de enemigos de la nación (1933-1946)}

El 31 de marzo de 1933 el presidente Terra, en representación tácita de una alianza golpista, dispuso una serie de medidas de excepción dirigidas contra los sectores del batllismo y del Partido Nacional que venían viabilizando la nueva legislación estatista. La Asamblea General decidió por mayoría dejar sin efecto

6 El Poder Ejecutivo es el responsable de la adopción de medidas prontas de seguridad y está obligado a rendir cuentas al Poder Legislativo dentro de las veinticuatro horas siguientes de todas las acciones realizadas durante su vigencia. El Parlamento tiene la potestad de mantener la vigencia de las medidas o de levantarla. Cfr. Artículo 168, inciso 17. Constitución de 1967 de la República Oriental del Uruguay, edición corregida al cuidado de Alberto Pérez Pérez, 1998: 60. 
esas medidas y, en respuesta, el presidente violó el ordenamiento jurídico: anuló el Poder Legislativo y disolvió una de las ramas del Poder Ejecutivo, entes autónomos y gobiernos departamentales. La prensa opositora fue censurada y se procedió a la destitución de varios funcionarios públicos. Desde el día del golpe y en los meses siguientes tuvieron lugar detenciones, encarcelamientos, deportaciones y destierros de políticos y sindicalistas opositores (González Sierra, 1989: 25; Porrini, 1994a: 140,1417). Desde el movimiento popular la respuesta más organizada fue la de la Federación de Estudiantes Universitarios, que se declaró en huelga y promovió una manifestación disuelta por la policía con singular violencia.

Suele afirmarse que en la coyuntura del golpe y la dictadura las Fuerzas Armadas no tuvieron participación directa (Ramírez, 1988: 167; Cocchi, Frega, Nahum y Trochon, 1994: 25), lo cual debería ser revisado y probablemente formulado en términos más cautos. ${ }^{8}$ Es innegable que la represión más ostensible estuvo a cargo de la Policía que, con uso de armas de fuego, sables y gases, estuvo encargada del patrullaje de calle, las detenciones, los allanamientos de locales y domicilios particulares y el control de las manifestaciones públicas. Fue, asimismo, el cuerpo a cargo de los interrogatorios llevados adelante mediante malos tratos y torturas. A esta impronta policíaca y a la auto-identificación del proceso por parte de los golpistas con la noción de "revolución" alude el testimonio de Emilio Frugoni, titulado La revolución del machete y publicado en Buenos Aires en 1934 durante el exilio de su autor (Frugoni, 1934). Otra de las características del golpe y del régimen que le sucedió fue el encarcelamiento de opositores, que en el marco de lo dispuesto por las medidas prontas de seguridad, se concretó en lugares de detención distintos a los de los presos por delitos comunes, en ello sobresalieron las dependencias militares. En este sentido, las Fuerzas Armadas participaron activamente en el control de los opositores detenidos.

Fueron varios los testimonios de políticos opositores que percibieron un cambio en la intensidad de la represión estatal. Resulta, no obstante, sugerente y acertada la invitación de Rodolfo Porrini (1994a: 123-158) a matizar esta percepción tan extendida en las crónicas de época, puesto que las modalidades represivas del terrismo no eran nuevas. Por el contrario, los detenidos y encarcelados por las denominadas "cuestiones sociales" eran regularmente objeto de malos tratos y tormentos -en particular en la Dirección de Investigaciones- y víctimas de la brutalidad policial en la disolución de las manifestaciones públicas. Según consigna Porrini, entre 1926 y 1933 se registraron varios casos de obreros asesinados por causa de la acción policial en distintas partes del territorio. Lo novedoso, entonces, habría sido la extensión de estas prácticas represivas a individuos pertenecientes a la élite social y política y esto en un momento histórico en el que los gobernantes ensalzaban el culto a la legalidad y el abandono de modalidades violentas de resolución de conflictos, que habían caracterizado al siglo XIX y el ciclo de las guerras civiles.

7 Los militantes sindicales españoles e italianos expulsados de Uruguay fueron entregados a las autoridades policiales de sus países de origen (Amorós, 2015: 22, 23).

8 Análisis históricos generales y sintéticos que evidencian la participación de las Fuerzas Armadas durante el terrismo en Real de Azúa (1969: 185) y Caetano y Jacob (1990: 170-173). 
En 1937 el diputado y líder del Partido Socialista, Emilio Frugoni, divulgó en la prensa la información que estaba siendo recabada por una Comisión Investigadora formada en el parlamento a raíz de las numerosas denuncias de torturas. A pesar de que la comisión desestimó las denuncias, el memorándum dado a conocer por Frugoni contenía declaraciones que no dejaban lugar a dudas. En el detalle del tipo de torturas a las que habían sido sometidos los presos políticos figuraba el uso del cepo americano y de esposas de criquet, los plantones con privación de sueño, simulacros de fusilamiento, "compresión con aparatos especiales en los órganos genitales hasta su trituramiento" y uso de la picana eléctrica. Frugoni añadía que este último instrumento de tortura ya era usado con frecuencia entre los delincuentes comunes (Porrini, 1994a: 131-133).

A diferencia de otros golpes de Estado ocurridos en la región por la misma época, el de Terra ha sido definido como un ajuste conservador moderado (Caetano y Jacob, 1990), centrado especialmente en el objetivo de desmontar la institucionalidad vigente e introducir algunas novedades en distintos niveles. Si bien tuvieron lugar varias olas represivas entre 1933 y 1938 -por lo general reactivas, como consecuencia de los esfuerzos de la oposición- el régimen terrista mostró una rápida vocación legalista, que se plasmó en 1934 en una nueva Constitución y un nuevo Código Penal (que casi no presentó variación en las definiciones de los delitos de "sedición" y "asonada"), así como en la convocatoria a elecciones sin proscripciones. En materia legal, buena parte de los esfuerzos estuvieron abocados a asegurar la propiedad de los lemas partidarios por parte de los sectores políticos que habían apoyado el golpe y a impedir la formación de frentes populares y amplias alianzas opositoras. No hubo partidos ilegalizados (las colectividades que no participaron de la vida cívica practicaron el abstencionismo por propia iniciativa, como forma de protesta) y la Constitución de 1934 consagró los llamados derechos sociales, entre los que figuraban la sindicalización y la huelga. Asimismo, durante todo el período se mantuvieron distintos canales para la participación del movimiento sindical organizado. Todo esto no significa que la dictadura haya sido "blanda" ${ }^{9}$ ni que hayan estado ausentes conductas autoritarias que venían aflorando descle antes del golpe.

Podría postularse -y esto ameritaría un esfuerzo analítico específico- que la violencia represiva del terrismo fue directamente proporcional a las características de una oposición conformada por un movimiento popular desorganizado y con bajo poder de movilización, que además no logró instancias de concertación más amplias. De acuerdo a la preocupación que estructura este texto, focalizada en las continuidades de las prácticas autoritarias y dinámicas represivas, el terrismo fue un régimen que empleó la legislación de excepción que le proporcionaba la constitución vigente (de 1919 y luego de 1934), a la vez que acentuó prácticas represivas imperantes y ensanchó el universo de conductas y sujetos a criminalizar. Fue, también, un momento fundacional en materia de disposiciones legales basadas en criterios científico-jurídicos que buscaban penalizar o sancionar a quien la

9 Durante mucho tiempo se identificó este régimen con una "dictablanda" que había contribuido a la reorganización institucional prácticamente sin violación de derechos humanos (Ruiz, 2010: 92). 
autoridad consideraba un peligro latente para la sociedad, al margen de que se verificara culpabilidad o delito y que sirvieron de base para la identificación y la irradiación de "enemigos" de la seguridad nacional en las décadas siguientes (Kierszenbaum, 2012: 87).

La inmigración "indeseable" se transformó en un problema de Estado que mereció la atención en el transcurso de la década de 1930. La ley migratoria de julio de $1932^{10}$ se amplió con sucesivos decretos, por ejemplo, el del 30 de agosto de 1933 que prohibió el ingreso al país de los extranjeros carentes de recursos para subsistir por el término de un año. En marzo de 1934 un decreto presidencial legisló sobre el "contralor sanitario de extranjeros" que estableció la pericia psiquiátrica obligatoria para quienes buscaban radicarse en el país. ${ }^{11}$ En 1936 la Ley 9.604 identificó de forma más precisa a los sujetos que podrían llegar a ser expulsados del territorio nacional por pertenecer a "organismos sociales o políticos que por medio de la violencia tiendan a destruir las bases fundamentales de la nacionalidad." Al mismo tiempo, de acuerdo a la disposición, no podían ingresar al país personas con enfermedades mentales, "los que padezcan enfermedades crónicas de los centros nerviosos", epilépticos, portadores de enfermedades infecto-contagiosas, "los toxicómanos y ebrios consuetudinarios, los que padezcan enfermedades orgánicas del corazón, los mendigos, todas aquellas personas cuyo estado de salud las imposibilite permanentemente para dedicarse a tareas que requieran esfuerzos físicos". ${ }^{12}$

La normativa delineaba el concepto médico-legal de "estado peligroso" que había arraigado en algunos círculos jurídicos y partidarios de concepciones criminológicas profilácticas. De acuerdo a esta visión, existían individuos que evidenciaban, por aspectos psíquicos, morales o posiciones políticas, proclividad a cometer algún tipo de atentado contra la propiedad privada o la vida, por lo que era fundamental combatir a los posibles delincuentes de forma previa a la comisión de un hecho ilegal. Este concepto estaba cargado de connotaciones morales, puesto que se partía del supuesto según el cual la sociedad necesitaba la aplicación de medidas represivas contra personas de dudosa conducta moral, cuyo estilo de vida ofrecía fundadas sospechas. Dentro de los tipos sociales pasibles de quedar englobados en esta disposición figuraban toxicómanos, ebrios consuetudinarios, homosexuales, así como colectividades de inmigrantes que se entendía a priori que atentaban contra la unidad nacional y militantes políticos, en particular comunistas y anarquistas. Tales postulados estaban en sintonía con la posición del redactor del Código Penal de 1934, José Irureta Goyena, firme defensor del concepto de "defensa social" e impulsor de un proyecto de ley presentado en 1937, cuya clave argumental radicaba en la necesidad de identificar una presunta

10 La ley de 1932 prohibía el ingreso de extranjeros, aunque fuesen ciudadanos legales uruguayos, que hubiesen sido condenados por delitos en el país o en el exterior; también se prohibía el ingreso de "vagos", "maleantes", "toxicómanos", "ebrios consuetudinarios", personas expulsadas de cualquier otro país $\mathrm{y}$ “los que sufr[ieran] enfermedades mentales. (Porrini, 1994b: 19).

11 "Contralor sanitario de extranjeros". Registro Nacional de Leyes y Decretos de la República Oriental del Uruguay. (1934). Montevideo: Imprenta Nacional, pp. 488, 489.

12 Ley 9.604. Extranjeros. Se amplían disposiciones relativas a su entrada y permanencia en territorio nacional. Registro Nacional de Leyes y Decretos (1937). Montevideo: Imprenta Nacional, pp. 740-753. 
culpabilidad con la finalidad de anticiparse a las posibilidades de cometer un daño social. En su exposición de motivos, en la que justificó la categoría de "estado peligroso", aludió a individuos "que por su mala conducta, antecedentes morales, género de vida, etc., se pueda inferir que pueden violar la norma y perturbar la paz social". ${ }^{13}$ La ley en cuestión se sancionó en 1941 con el nombre de "Ley de Vagancia, Mendicidad y Estados Afines”. ${ }^{14}$

Desde 1938, factores políticos internos y las repercusiones del contexto internacional en la antesala de una nueva guerra mundial provocaron la ruptura de la alianza "marzista" que sostenía el régimen terrista. El presidente Alfredo Baldomir, un militar y arquitecto, que se había desempeñado como Jefe de Policía de Montevideo en el golpe de Estado de 1933, buscó rápidamente dejar atrás su protagonismo en este proceso. El cambio de rumbo recogía el sentir de amplios sectores de la sociedad uruguaya movilizados a favor de "nueva Constitución y leyes democráticas". Pero también respondía a la cada vez más intensa influencia de Estados Unidos y su prédica antifascista y defensora de la democracia liberal. Al igual que otros países americanos, Uruguay asistía a la consolidación de Estados Unidos como potencia occidental hegemónica, experimentando durante la guerra el tránsito de una neutralidad pro-Aliados hacia una identificación absoluta con el panamericanismo y la idea de una defensa hemisférica liderada por el país del norte. Baldomir encabezó una transición democrática que derivó en un nuevo auto-golpe el 21 de febrero de 1942, sin violación de las libertades individuales, que dio paso a un período de un año en el que se concretó la reforma constitucional que puso fin a la institucionalidad del terrismo. ${ }^{15}$

Antes del golpe de 1942, el gobierno uruguayo se mostró comprometido con la sanción de legislación concebida para controlar supuestos vínculos locales con la Alemania nazi. Se trató de un corpus de disposiciones "patrióticas" y antitotalitarias. En junio de 1940 se aprobó la Ley de Sociedades Ilícitas, definidas como aquellas "que difundan ideas contrarias a la forma de gobierno democrático-republicana", "[1]as de carácter político o social” que "en su organización o funcionamiento o directrices o finalidades o provisión de recursos, estén vinculadas a la voluntad de una persona o de un poder extranjero, o de cualquier entidad extraña al país". ${ }^{6}$ Inicialmente esta legislación estuvo destinada a la prohibición de las pequeñas agrupaciones antiliberales y filo-fascistas surgidas en las décadas de 1930. Sin embargo, ya en 1940 ocho sindicatos fueron enjuiciados como agentes de propaganda y acción política antinacionales (González Sierra, 1989: 27). Mientras esto ocurría, las públicas y notorias simpatías frente a las experiencias fascistas, que en los años anteriores habían aflorado en gran parte del elenco terrista, empresarios y jerarquías eclesiásticas, fueron desapareciendo del espacio público. También se

13 Diario de sesiones de la Cámara de Representantes (1937). Montevideo: Imprenta Nacional.

14 Ley 10.071. Vagancia, mendicidad y estados afines (14 de octubre de 1941). Registro Nacional de Leyes y Decretos (1954). Montevideo, Imprenta Nacional, pp. 1026-1032.

15 Un panorama sobre el gobierno de Baldomir y las posiciones aliadófilas en el marco de la Segunda Guerra Mundial, así como los cambios en las internas políticos partidarias, puede verse en Frega, Maronna y Trochón (1987).

16 Registro Nacional de Leyes decretos y otros documentos de la República Oriental del Uruguay (1941). Montevideo: Imprenta Nacional: 365, 366. 
redujo sustancialmente el coro de voces antisemitas, muy presente en el período anterior. En 1942 se formó en la órbita parlamentaria una Comisión Investigadora de Actividades Antinacionales que indagó acerca de supuestos vínculos políticos locales con las potencias del Eje (Ruiz, 2010: 133, 134).

La común percepción de amenaza ante el peligro nazi-fascista y la entrada de la URSS al campo aliado reunieron en el frente antitotalitario a sectores de derecha e izquierda. En el primer lustro de la década de 1940 se construyó desde el gobierno, con apoyo mediático, la idea de un común enemigo fascista que había que desarticular. La segunda etapa de la transición hacia la democracia transcurrió entre 1943 y 1946, en simultáneo con el último tramo del conflicto bélico y la instauración definitiva de un nuevo orden mundial, en el que Estados Unidos ocuparía un lugar hegemónico. El discurso antifascista del bando de los Aliados, que ensalzó la libertad y la democracia como valores supremos, propició indirectamente en varios países latinoamericanos la movilización social y política. En Uruguay esto se tradujo en el crecimiento numérico y organizacional de los sectores trabajadores, en un contexto de apuesta a la industrialización por sustitución de importaciones. A su vez, los años finales de la guerra fueron de fermento para la movilización concertada entre partidos políticos y movimientos sociales.

\section{Radicalización política, movilización sindical y autoritarismo (1947-1973)}

Con el final de la guerra, la derrota del nazi-fascismo y el fortalecimiento de la URSS como potencia mundial antagonista de los Estados Unidos, el campo "demócrata" adquirió nuevas connotaciones: el comunismo, aliado circunstancial en los años anteriores, pasó a ser recurrentemente señalado como la principal expresión de totalitarismo. El antisovietismo, reconocible en varios actores sociales y en actitudes del Estado, no aludía estrictamente al comunismo doctrinario. Por el contrario, comprendía un amplio abanico de expresiones partidarias, sociales y culturales de izquierda, que quedaron retóricamente ubicadas dentro del espacio conceptual y simbólico del "comunismo" o su equivalente, el "totalitarismo". ${ }^{17}$ Este viraje de inicios de la Guerra Fría incidió en las justificaciones estatales en el empleo de la violencia represiva y la legalidad de excepción, así como en las características de la vigilancia política preventiva.

En la primera etapa de este amplio período, comprendido entre la posguerra y el final de la década de 1950, la represión estatal estuvo enfocada sobre todo en la contención del movimiento sindical. Aunque no faltaron iniciativas tendientes a ilegalizar al Partido Comunista, esto no se concretó y la organización mantuvo su actividad legal hasta el golpe de Estado de 1973. La izquierda política, conformada entre otros por comunistas y socialistas, continuó teniendo un techo electoral muy bajo hasta su convergencia en el Frente Amplio en las elecciones de 1971. Sin

17 Ernesto Bohoslavsky y Mariana Iglesias (2014: 113-133) han señalado este rasgo en común en los inicios de la Guerra Fría en la región. 
embargo, en esta fase creció la preocupación de las agencias estatales encargadas de la seguridad interior por la influencia comunista en organizaciones gremiales, sindicales y culturales. Esto preocupaba no sólo hacia dentro de las fronteras sino también en términos regionales, puesto que Uruguay, por varios motivos, entre los que sobresalían su ubicación geográfica, su legislación en materia de derecho de asilo y el insuficiente control de las zonas fronterizas, continuaba siendo un lugar de pasaje y encuentro de activistas de izquierda del Cono Sur.

Las modalidades represivas se caracterizaron por la apelación a la ilicitud de la huelga cuando se trataba de empleados públicos, la adopción de medidas prontas de seguridad para intervenir en conflictos sindicales y la acción de la Policía, tanto en el control de las manifestaciones y medidas sindicales como en la vigilancia e intercambio de información con sus pares de la región. En 1947 se creó el Servicio de Inteligencia y Enlace, una repartición que continuó con la labor de control y vigilancia de individuos y agrupaciones gremiales, políticas y culturales laxamente catalogadas como "comunistas", y que desde sus orígenes mantuvo estrechas relaciones con la agencia central de inteligencia estadounidense (CIA) (Aparicio, García, Terra, 2013: 17-28). En los contextos de medidas prontas de seguridad, las Fuerzas Armadas tuvieron un desempeño activo y coordinado con la Policía.

El breve gobierno de Tomás Berreta en el primer semestre de 1947 se desarrolló en un marco de creciente agitación sindical, en particular en las ramas de la construcción en el sector privado y los ferroviarios en la órbita pública. En mayo el presidente envió al Ejército a desarticular la huelga de la Unión Ferroviaria, aplicó por primera vez el artículo 165 del Código Penal de 1934 que establecía la ilicitud de la huelga y procesó con prisión a siete dirigentes sindicales. Poco después el Parlamento aprobó una ley que mantenía el carácter ilícito de la huelga en el sector público, pero establecía mecanismos de mediación para atender situaciones de conflictos. En paralelo, en la órbita del gobierno, fueron varios los proyectos que se promovieron para reglamentar la acción sindical. Aunque no logró concretarse ninguna iniciativa en este sentido, en adelante el tópico se transformó en un tema recurrente en la consideración de la cada vez más vigorosa agitación sindical.

La inesperada llegada de Luis Batlle Berres (Partido Colorado) a la Presidencia matizó la propensión represiva que caracterizó al Poder Ejecutivo en la breve administración de Berreta, fallecido en agosto de 1947. Sin embargo, en 1948 militantes comunistas irrumpieron en una sala de cine durante la proyección de "La cortina de hierro", una película de sesgo anticomunista que había causado protestas en varias partes del mundo. Los manifestantes impidieron la proyección lanzando tubos de alquitrán contra la pantalla y enfrentándose con los espectadores y la Policía (Leibner, 2011: 104-110). Treinta personas fueron detenidas y procesadas por "asonada" debido a esta acción, que desde las filas comunistas se criticó por haber causado una reacción social desfavorable (Aparicio y García, 2010: 40-45). Tras ser liberados, los detenidos denunciaron haber sufrido malos tratos y torturas por parte de la policía de investigaciones. El final de la presidencia de Batlle Berres -y en particular el año 1950- estuvo atravesado por grandes 
huelgas en la órbita pública y privada (industria de la lana y el cuero, ferroviarios, portuarios, metalúrgicos) y episodios de desborde policial, justificados por las autoridades de gobierno.

En el bienio 1951-1952 los conflictos sindicales se intensificaron significativamente. Se destacó la huelga de empleados y obreros de ANCAP en 1951 por haber concitado la adhesión de unos cuarenta mil obreros de "gremios solidarios" (Cores, 1989). El gobierno enfatizó en la violencia de los huelguistas. Después de este conflicto se formó una nueva comisión investigadora a raíz de las denuncias de apremios físicos por parte de la policía. Al año siguiente, en un contexto de alta conflictividad en varios sectores públicos, el Poder Ejecutivo dispuso dos veces medidas prontas de seguridad. En marzo de 1952 el estado de excepción se definió ante la huelga de trabajadores de Salud Pública. Durante todo el mes de setiembre las medidas se adoptaron en una coyuntura de paros en el transporte público, la ANCAP y la industria textil. Finalmente, en noviembre, el Poder Ejecutivo las reimplantó alegando un estado de "subversión peronista y comunista" en los sindicatos. ${ }^{18}$ No era una novedad la equiparación del peligro "peronista" con el "comunismo", puesto que para la mayoría de las derechas uruguayas en los tempranos años cincuenta el movimiento peronista representaba una amenaza totalitaria mucho más peligrosa y cercana que el comunismo soviético. En los inicios de la Guerra Fría el autodenominado movimiento antitotalitario que se formó en distintos departamentos de Uruguay respondió en gran medida a la convicción de que se estaba ante un momento de infiltración peronista en sindicatos y organizaciones sociales.

En 1952 el Ejército y la Marina tuvieron a su cargo el mantenimiento de los servicios públicos en conflicto y el control de los detenidos en el marco del estado de excepción. Quedó, además, suspendida la libertad de reunión y de asociación. Los legisladores de la izquierda y algunos colorados independientes, que se opusieron a las medidas durante su consideración en la Asamblea General, subrayaron la existencia de otros caminos para abordar la conflictividad sindical en las reparticiones del Estado, en alusión directa al artículo del Código Penal que establecía su ilicitud y a la "ley de indeseables", que habría permitido expulsar a los supuestos agitadores extranjeros que, según se expresó, organizaban soviets en hospitales públicos. ${ }^{19}$ El Ministro de Defensa reconoció que la "conmoción interna" que justificaba las medidas no era tan extrema pero las defendió, al igual que los legisladores que respaldaron su aplicación, por las características de la movilización sindical: solidaria, significativa desde el

18 Registro Nacional de Leyes y Decretos de la República Oriental del Uruguay (1952). Montevideo: Imprenta Nacional: 368. El conflicto fue seguido por la prensa, que elaboró consideraciones negativas sobre los huelguistas (a los que vinculó con el comunismo) y pidió reglamentar el derecho de huelga. A modo de ejemplo: (22 de marzo de 1952), Las medidas extraordinarias, La Mañana, p. 3 ; (25 de marzo de 1952), El comunismo y el conflicto que se ha planteado en Salud Pública, La Mañana, p. 3); (21 de marzo de 1952), La huelga subversiva, El País, p. 3); (25 de marzo de 1952), Servidores del comunismo, El Día, p. 7; (27 de marzo de 1952), Terminar con la subversión, El Debate, p. 3; (30 de marzo de 1952), iAcabar con la delincuencia social!, El Debate, p. 3. 
punto de vista cuantitativo y percibida como parte de un plan del comunismo internacional para apoderarse de los principales centros estatales.

En este breve repaso puede apreciarse que las transformaciones experimentadas por los trabajadores organizados desde mediados de los años cuarenta, así como el sesgo anticomunista en clave de Guerra Fría, que matrizó la interpretación de los conflictos sociales de la élite gobernante, son dos aspectos a profundizar en el análisis de la represión estatal a la movilización sindical (en particular en la órbita pública) de estos años. No debería pasar desapercibido que, después de la ola de conflictos, en marzo de 1953, una extensa ley de presupuesto de gastos y sueldos del Estado, incluyó un artículo que establecía que "ser[í]a condición indispensable para el ingreso a todos los cargos de la Administración Pública, incluso de los Entes Autónomos y Servicios Descentralizados, probar notoria filiación democrática” (Ley 11.923).$^{20} \mathrm{En}$ los tempranos años sesenta varios consejeros del gobierno colegiado recogieron la preocupación de numerosas organizaciones civiles movilizadas para enfrentar lo que entendían como infiltración del comunismo en la enseñanza, los sindicatos, la cultura y la administración pública y promovieron una ley que reglamentara la vigilancia ideológica establecida en la norma de 1953 (Broquetas, 2018: 34-54).

Los largos años sesenta (1959-1973) fueron escenario tanto de la radicalización de la protesta social como de ascenso del autoritarismo del Estado. En 1958 se produjo la victoria electoral del sector herrerista del Partido Nacional (aliado con el ruralismo), representante de intereses de las clases altas rurales, que ansiaban poner freno al modelo urbano-industrial. En un contexto de viraje económico liberal, espiral inflacionaria, descenso del poder adquisitivo de los sectores asalariados y pasivos y alto grado de movilización gremial de obreros, empleados y jubilados, que se tradujo en numerosos paros y huelgas y en ingentes esfuerzos de unificación sindical, el Estado adquirió desde los primeros años de la década visos autoritarios (Alonso y Demasi, 1986; Frega, Maronna, Nahum y Trochón, 1993).

Como se ha dejado en evidencia, la preocupación por la huelga en la órbita estatal venía in crescendo en relación directa con los cambios atravesados por el sindicalismo de masas en los veinte años previos. En 1964 los sindicatos de trabajadores del Estado potenciaron su capacidad de presión a través de la creación de un espacio de unificación (Confederación de Organizaciones de Funcionarios del Estado). Entre 1963 y 1965 el Poder Ejecutivo dispuso en varias oportunidades medidas prontas de seguridad para desarticular conflictos de trabajadores del Estado en áreas industriales y de servicios. Antes y después se produjeron sanciones y despidos masivos. En una interpelación al ministro de Salud Pública en mayo de 1960 el diputado colorado Zelmar Michelini denunció el procesamiento de dirigentes sindicales a través de la tipificación de delitos de orden penal común:

más que los palos en la calle, más que el cierre de sindicatos, más que la persecución, más, inclusive, que el hambre o el sacrificio de algunos dirigentes, es la cárcel para hombres y mujeres primarios que nunca la conocieron; hombres y mujeres de

20 Presupuesto general de gasto. Registro Nacional de Leyes y Decretos (1954). Montevideo: Imprenta Nacional: 225-350. 
buena familia, sin antecedentes penales de ninguna clase, estimados por sus propios compañeros, estimados por los vecinos de la zona donde viven, hombres con 30 y 35 años de funcionarios y mujeres con 15 y 20 años de funcionarias, que de la noche a la mañana son llevados a la cárcel y alojados como delincuentes. [...]. ${ }^{21}$

Esta modalidad represiva adquirió regularidad en la primera mitad de la década de 1960 y se fue afianzando en simultáneo con la construcción del estereotipo del trabajador sindicalizado como "enemigo interno" y caballo de Troya del comunismo internacional (Broquetas, 2014: 79-123).

En simultáneo al uso cada vez más frecuente del recurso legal de estado de excepción, la violencia represiva se transformó en una respuesta habitual por parte del Estado y siguió estando encomendada fundamentalmente a la Policía y, en menor grado, a las Fuerzas Armadas. Ambos cuerpos atravesaron un proceso de modernización y tecnificación mediante los programas de asistencia policial y militar financiados por el gobierno de Estados Unidos desde la primera mitad de la década. El apoyo estadounidense se canalizó por distintas vías, entre las que sobresalen los cursos de entrenamiento en el país y en el exterior, la prestación de asesoría técnica y el suministro de tecnología represiva adaptada a las nuevas necesidades. A su vez, la influencia estadounidense en la política interna uruguaya se tradujo en la presencia de funcionarios de ese gobierno que, por intermedio del Programa de Seguridad Pública dependiente de la Agencia Internacional para el Desarrollo (AID) y del Grupo Militar de la Embajada, planificaron, promovieron y supervisaron buena parte de las acciones represivas del período (Aldrighi, 2007: 379-407).

El retorno del Partido Colorado al poder en 1967 profundizó las modalidades vigentes de contención y castigo a la protesta social. Aunque el presidente Oscar Gestido intentó morigerar la propensión represiva que había caracterizado al lustro anterior, el año finalizó con saldos muy negativos en esta materia. En octubre volvieron a decretarse medidas prontas de seguridad para enfrentar la conflictividad gremial y en diciembre, una semana después del fallecimiento de Gestido, el gobierno de su sucesor, Jorge Pacheco Areco, promulgó un decreto que ilegalizó agrupaciones políticas (Partido Socialista, Movimiento Revolucionario Oriental, Federación Anarquista Uruguaya, Movimiento de Izquierda Revolucionario, y al Movimiento de Acción Popular Uruguayo) y clausuró los periódicos El Sol y Época, disponiendo la captura del consejo editorial de este último. La medida se debía al apoyo dado por estos grupos a la vía armada como alternativa política.

Desde junio de 1968 hasta el golpe de Estado de junio de 1973, tanto el Poder Ejecutivo como el Legislativo, promovieron frecuentes situaciones de abuso de la legalidad prevista constitucionalmente para casos de excepción. En este aspecto se destaca la disposición reiterada por parte del Poder Ejecutivo de medidas prontas de seguridad, que viabilizaron la alteración de derechos y garantías fundamentales (derecho de reunión, garantías en el debido proceso penal, por nombrar 
algunos de los más transgredidos) y limitaron a libertad de expresión y de prensa, al punto que para el momento del golpe las detenciones por lapsos más o menos prolongados, los allanamientos a locales públicos y domicilios particulares y la censura de prensa eran situaciones cotidianas (Gillespie, 1984; Broquetas, 2007). En 1968 el gobierno de Pacheco decretó la movilización de funcionarios públicos, con lo cual profundizó el proceso de politización de las funciones de las Fuerzas Armadas, que ya venían encargándose de la represión de los conflictos laborales y el mantenimiento de los servicios estatales en el marco de nuevas medidas prontas de seguridad. En setiembre de 1971, a través de un decreto que encomendaba a los mandos militares la "lucha antisubversiva" se amplió aun más el espacio de acción política de las Fuerzas Armadas (López, 1985: 145-188).

La práctica de torturas por parte de la Policía a trabajadores y dirigentes sindicales estuvo presente desde comienzos de la década y se transformó en norma después de 1968. No se trató de castigos arbitrarios o desbordes individuales, sino de una vasta gama de torturas metódicamente administradas y aplicadas. La ampliación del universo de "enemigos", que en la segunda mitad de la década comprendió también a militantes del movimiento estudiantil, organizaciones políticas, culturales y religiosas y grupos de izquierda armada, hizo de la tortura una práctica habitual y extendida entre grupos de procedencia social y generacional muy variados. Tal como se reconoció oficialmente en un informe elaborado por una comisión especial del Senado en julio de 1970 "el sistema de aplicación de trato inhumano y torturas a los detenidos por la Policía de Montevideo [era] un hecho habitual y se ha[bía] convertido en un sistema frecuente, casi normal.” ${ }^{22}$

Otro instrumento a destacar de la escalada represiva y de control social fue la promulgación por decreto de un "Registro Nacional de vecindad" (20 de mayo de 1971), que estableció disposiciones "referidas a la información sobre identidad y avecinamiento de los habitantes" para adecuarlas a "la defensa de las instituciones y de las personas." A través de esta disposición -que recogía una iniciativa discutida desde la década de 1930- los habitantes de cada barrio tenían que completar un formulario con datos filiatorios que constaba de dos vías: una para la comisaría y otra que quedaba en poder de la persona. Asimismo, los propietarios de hoteles, pensiones y casas de alojamiento estaban obligados a comunicar a la comisaría seccional el movimiento diario de sus establecimientos. El mensaje del Poder Ejecutivo señalaba que el registro de vecindad era una alternativa a la propuesta presentada en 1969 para crear un Registro Permanente de Población, que las cámaras no habían aprobado. ${ }^{23}$

En simultáneo a esta escalada autoritaria, el oficialismo cuestionaba la actuación de los jueces, alegando que las disposiciones jurídicas vigentes en materia penal resultaban demasiado benignas con los detenidos por motivos políticos. El trasfondo de estas críticas era un cuestionamiento a la autonomía del Poder Judicial.

22 Cuadernos de Marcha, 1970: 29-74.

23 “Decreto 278/971. Registro Nacional de vecindad. Se crea". Registro de Leyes y Decretos de la República Oriental del Uruguay (1972). Montevideo: Imprenta Nacional, vol. I: 913-915. 
Desde 1970, hubo propuestas de crear tribunales especiales para los detenidos por participar en organizaciones guerrilleras, endurecer los deberes punitivos del Estado y se tipificaron algunas figuras previstas en el Código Penal Militar. Esta forma de proceder se combinó con otras estrategias, como el rechazo del Poder Ejecutivo a reconocer el derecho de habeas corpus durante la aplicación de medidas prontas de seguridad, la potestad conferida a los jueces militares para emitir órdenes de allanamiento de viviendas particulares y la incomunicación prolongada a la que eran sometidos los detenidos, todo lo cual conformó una situación excepcional que devino en habitual (Duffau, Rico, 2012: 46).

En julio de 1971 la Suprema Corte de Justicia promovió un juicio político contra el presidente Pacheco, al que acusaban de violación de la Constitución por el reiterado uso de medidas excepcionales para gobernar. La iniciativa no prosperó por no contar con los votos necesarios en el Senado, pero las relaciones entre el Poder Ejecutivo y el Judicial se tensaron cada vez más (Duffau, Rico, 2012). Las cámaras legislativas complementaron la legislación de excepción adoptada sistemáticamente por el Poder Ejecutivo autorizando la "suspensión de garantías individuales" en dos oportunidades antes del golpe de Estado (agosto de 1970 y abril de 1972) y aprobando en 1972 el "estado de guerra interno" y la "ley de seguridad del Estado", que habilitaban definitivamente la aplicación de la Justicia Militar a civiles. Estas disposiciones respondieron a acciones del Movimiento de Liberación Nacional-Tupamaros, la organización de izquierda armada de mayor proyección en Uruguay entre 1968 y 1972. Sin embargo, una vez que la guerrilla fue militarmente desarticulada en julio de 1972, la arquitectura legal autoritaria se mantuvo y continuó siendo la piedra angular para la represión de la oposición de movimientos sociales y políticos (Frega, Maronna, Nahum y Trochón, 1993: 84-96; Aldrighi, 2001:115-118).

Este fue, por cierto, un contexto propicio para que recobrara fuerza la legislación vinculada a los llamados delitos latentes, que conferían al Estado la potestad de adoptar medidas preventivas para penalizar a quienes representaban un peligro social, incluyendo opositores políticos, sindicalistas y delincuentes comunes. La posibilidad de anticiparse a los acontecimientos permitía, por ejemplo, detener y fichar obreros y empleados o funcionarios públicos que participaban de movilizaciones sindicales (Kierszenbaum, 2012: 175). El proyecto sobre "estado peligroso" elaborado por Alejandro Rovira y presentado a la Cámara de diputados el 21 de marzo de 1973 intentaba mantener la lucha contra la subversión pues si bien, como señalaba la exposición de motivos, “[m]ilitarmente [...][esta] ha[bía] sido derrotada", "las organizaciones subsisten y el peligro de su reorganización y reactivación está latente." Por eso se requerían "medidas de seguridad preventivas, predelictuales". La referencia era la ley de octubre de 1941 que entendía como estados peligrosos a la vagancia, mendicidad y estados afines. Los integrantes de organizaciones llamadas subversivas evidenciaban una "peligrosidad" que llevaba a justificar plenamente medidas preventivas ante posibles delitos antinacionales. Lo novedoso de la propuesta era que en los casos en que la conducta de una persona "represent[ara] un peligro para la seguridad del estado y el orden público" sería un tribunal penal militar el que se encargaría de juzgar e impartir las medidas, 
que podían ser internación en establecimientos penitenciarios y psiquiátricos, prisión domiciliaria o seguimiento mediante vigilancia, entre otras. ${ }^{24}$

Si bien ha transcurrido casi medio siglo desde la ruptura institucional ocurrida el 27 de junio de 1973, aún faltan explicaciones históricas sólidas y que den cuenta de la multiplicidad de factores en juego detrás de la decisión del golpe de Estado en Uruguay. La historiografía ha destacado los siguientes motivos: la autonomización irreversible del poder militar (incorporado plenamente a funciones de gobierno y justicia desde el mes de febrero), cierta reactivación opositora por parte del Parlamento entre marzo y junio y la masiva movilización popular, que se expresaba en medidas de lucha sindical y multitudinarias manifestaciones callejeras, así como en el crecimiento de la coalición política de izquierdas Frente Amplio, que en los comicios nacionales de noviembre de 1971 había concitado más del 18\% del total de los votos, luego de una campaña electoral con activa participación popular, sobre todo en la capital del país.

\section{Conclusiones}

La consideración de las características de la violencia estatal en un período amplio, atento a los procesos de movilización social y consolidación de la democracia política desde los primeros años del siglo XX, permite reconocer matrices y continuidades que incitan a revisar algunas ideas preconcebidas acerca de la excepcionalidad del Uruguay en la región y de la última dictadura en relación a las formas previas de resolución de conflictos sociales. En lo que refiere a los grupos sociales sobre los que mayoritariamente recayó la represión del Estado figuran desde fines del siglo XIX trabajadores sindicalizados, anarquistas, militantes de las izquierdas y opositores políticos de los partidos mayoritarios (Colorado y Nacional). En simultáneo a la dimensión política, puede reconocerse una continuidad en la represión a grupos considerados "marginales", noción que comprendía prostitutas, enfermos mentales, homosexuales y colectivos de inmigrantes que despertaban sospechas por su procedencia étnica o asociación con las izquierdas.

Tanto la represión física como la vigilancia política de grupos considerados peligrosos dentro del territorio uruguayo (izquierda sindical y grupos antisistema) estuvo históricamente a cargo de la Policía, pero esto no significó ausencia del brazo militar, que a partir de la década de 1910 protagonizó episodios de represión conjunta de las izquierdas. Desde los primeros grandes conflictos sindicales del siglo XX, las Fuerzas Armadas contribuyeron en las tareas represivas mediante patrullajes, control de zonas en conflicto y mantenimiento de los servicios paralizados.

Otro de los rasgos tempranos del control y el castigo a la disidencia social y política fue la coordinación represiva de la Policía uruguaya con sus pares de la región, lo 
cual respondió directamente a la internacionalización de los vínculos de movimientos gremiales y políticos de izquierda. Entre las modalidades represivas se identificaron continuidades en los desbordes de los cuerpos policiales, sobre los cuales recayeron denuncias sobre malos tratos y torturas a detenidos en distintos momentos de la centuria. Además de la represión física, la modalidad del encarcelamiento y el destierro fueron otros rasgos de larga duración. Finalmente, entre los instrumentos clave en la represión a la protesta social y la disidencia política estuvo siempre la ley. El Estado garantizó la dominación a través del recurrente uso de leyes previstas para casos de excepción ("conmoción interior" o estado de "subversión") que suspendían derechos y libertades, así como mediante el uso de normas que criminalizaban algunas formas de la protesta social o buscaban limitar el accionar de los sindicatos.

En el proceso descripto, a lo largo del siglo XX el control del Estado -y por consiguiente de las definiciones en materia represiva- estuvo en forma alternada en manos de los partidos Nacional y Colorado, que en varias ocasiones cogobernaron a través de diferentes mecanismos de coparticipación. No obstante, fue recurrente, en particular en contextos de crisis política y económica, tanto la presión ejercida por grupos patronales y empresariales como por actores transnacionales vinculados a la diplomacia política y comercial.

El proceso de construcción de enemigos internos y el recorte de la dimensión política de la protesta social no fue algo que ocurrió en forma abrupta en la fase previa al golpe de Estado de 1973. Por el contrario, representó una constante en las respuestas estatales ante la presión de grupos subalternos o que cuestionaran el orden establecido. Cabe subrayar también la lenta y sostenida construcción del estereotipo estigmatizante del "comunista" como un "otro" al que había que exterminar porque no pertenecía a una imaginada comunidad nacional; prédica que fue acompañada por el intento de criminalizar la protesta social y llevó la dimensión política de los movimientos sociales a la órbita del delito.

Desde luego que no se trata aquí de magnificar la violencia estatal en contextos anteriores a la dictadura sino de llamar la atención en relación a lo perdurable de algunas prácticas represivas y conductas autoritarias, fundamentalmente en contextos democráticos. La intensidad de la represión fue en aumento en estrecha relación con el crecimiento y la radicalización de la movilización social (sindical, estudiantil, guerrillera, político-partidaria) pero, incluso en los momentos de mayor violencia, en la fase previa al golpe de Estado de 1973, no eran nuevos los métodos. La novedad radicó en la autonomización y politización de la Fuerzas Armadas, el aumento de la injerencia estadounidense en el sistema represivo y el ensanchamiento del universo de sujetos y grupos sociales pasibles de ser reprimidos.

Como se señaló en la introducción, el mapeo propuesto en este artículo relativo a las prácticas represivas y conductas autoritarias del Estado uruguayo a lo largo de ocho décadas no se pretende concluyente, ni mucho menos aspira a explicar las razones del golpe de Estado de 1973. Se buscó, en efecto, visibilizar 
la perdurabilidad de ciertas prácticas, argumentaciones y sensibilidades políticas procurando deconstruir la idea de excepcionalidad de esta última ruptura democrática y apostando a alentar cauces de investigación que ensanchen las periodizaciones y los factores a tomar en cuenta. Este artículo demuestra que en el período de mayor autoritarismo y desborde represivo los respectivos gobiernos se ampararon en leyes y figuras delictivas ya existentes y buscaron generar consenso social haciendo un uso abusivo de estereotipos criminalizadores arraigados históricamente. Creemos, por lo tanto, que solamente un enfoque minucioso centrado en la perdurabilidad de: a) los institutos de represión estatal previstos en la Constitución y en las normas jurídicas en materia penal, b) las prácticas de contención y represión de la protesta social y la disidencia política y c) las modalidades de resolución de crisis políticas podrá ofrecer evidencia empírica para calibrar continuidades y rupturas en la propensión y actitud represiva del Estado.

Resulta también fundamental preguntarse con mayor sistematicidad por los actores sociales que impulsaron y justificaron prácticas represivas desde el Estado (dentro de partidos políticos, grupos de presión, fuerzas de seguridad, iglesias), así como por su peso relativo en las distintas coyunturas históricas. Esto supone visibilizar más y mejor a la derecha en sus vertientes políticas, sociales, empresariales y religiosas y el tipo de dinámica social establecida con los poderes estatales. Serían deseables, asimismo, investigaciones que trasciendan el marco de análisis nacional y observen este fenómeno en clave comparada con los países del Cono Sur de América Latina en los que, pese al predominio de imaginarios nacionales distintos al de Uruguay, ocurrieron desenlaces históricos equiparables desde el punto de vista represivo. 


\section{Q Bibliografía}

" Albornoz, M. y Galeano, D. (2017). Anarquistas y policías en el Atlántico sudamericano: una trama transnacional, 1890-1910. Boletín del Instituto de Historia Argentina y Americana "Dr. Emilio Ravignani", 47, pp. 101-134.

" Aldrighi, C. (2000). La ideología antisemita en Uruguay. Su contexto católico y conservador (1870-1940). Abend, G., Aldrighi, C., Camou, M. y Feldman, M. Antisemitismo en Uruguay. Raíces, discursos, imágenes (1870-1940). Montevideo: Trilce: pp. 129-224.

" Aldrighi, C. (2001). La izquierda armada. Ideología, ética e identidad en el MLNTupamaros. Montevideo: Trilce.

" Aldrighi, C. (2007). El caso Mitrione. La intervención de Estados Unidos en Uruguay (19651973). Montevideo: Trilce.

" Alonso, R., Demasi, C. (1986). Uruguay 1958-1968: crisis y estancamiento. Montevideo: Ediciones de la Banda Oriental.

"Amorós, M. (2015). Francisco Carreño. Del sindicato del automóvil a la revolución española. Montevideo: La Turba Ediciones.

" Aparicio, F., García, R. (2010). El Cine Trocadero, un testigo de la Guerra Fría. Contemporánea. 1, pp. 27-49.

" Aparicio, F., García, R., Terra, M. (2013). Espionaje y política. Guerra Fría, Inteligencia Policial y Anticomunismo en el sur de América Latina. 1947-1961. Montevideo: Ediciones B.

" Armand Ugon, E. Cerdeiras J. Alonso, L. Arcos Ferrand, C. Goldaracena (1930). Compilación de Leyes y Decretos. Montevideo: s.d., tomo LIV, segunda parte, 1926-1927.

" Balbis, J. y Zubillaga, C. (1985). Historia del movimiento sindical uruguayo. Montevideo: Ediciones de la Banda Oriental, vol. I.

" Barrán, J.P. y Nahum, B. (1972). Historia rural del Uruguay moderno. Historia social de las revoluciones de 1897 y 1904 . Montevideo: Ediciones de la Banda Oriental.

" Barrán, J.P. y Nahum, B. (1983). Batlle, los estancieros y el Imperio Británico. Montevideo: Ediciones de la Banda Oriental, vol. IV.

" Barrán, J.P. y Nahum, B. (1987). Batlle, los estancieros y el Imperio Británico. Montevideo: Ediciones de la Banda Oriental, vol. VIII.

" Barrán, J.P. (2004). Los conservadores uruguayos (1870-1933). Montevideo: Ediciones de la Banda Oriental.

" Bohoslavsky, E. e Iglesias, M. (2014). Las guerras frías del Cono Sur: Argentina, Brasil, Chile y Uruguay (1945-1952). OPSIS, 14, pp. 113-133.

" Broquetas, M. y Bruno, M. (2012). La fotografía al servicio de la vigilancia y el control social. 1870-1925. Broquetas, M. (coord.). Fotografía en Uruguay. Historia y usos sociales. 1840-1930. Montevideo: Centro de Fotografía, pp. 176-198.

"Broquetas, M. (2007). Liberalización económica, dictadura y resistencia. 1965-1985. AA.VV. Historia del Uruguay en el siglo XX. 1890-2005. Montevideo: Ediciones de la Banda Oriental, pp. 163-210.

"Broquetas, M. (2014). La trama autoritaria. Derechas y violencia en Uruguay (1958-1966). 
Montevideo: Ediciones de la Banda Oriental.

" Broquetas, M. (2018). Un caso de anticomunismo civil: los "padres demócratas" de Uruguay (1955-1973). Páginas, 24, pp.34-54.

"Broquetas, M. (2019). Las derechas uruguayas en los años veinte. Bohoslavsky, E., Jorge. D., Lida. C. (coord.). Las derechas iberoamericanas. Desde el fin de la Primera Guerra hasta la gran depresión. México, D.F.: El Colegio de México, pp. 157-188.

" Bruno, M. (2007). La caza del fantasma. Benito Nardone y el anticomunismo en Uruguay (1960-1962). Montevideo: FHCE.

"Bucheli, G. (2012). Organizaciones "demócratas" y radicalización anticomunista en Uruguay, 1959-1962. Contemporánea, 3, pp. 31-52.

"Caetano, G. (1992). La República Conservadora. 1916-1929. El alto a las reformas. Montevideo: Fin de Siglo.

"Caetano, G. (2016). La vida política. Caetano, G. (coord). Uruguay. Reforma social y democracia de partidos. 1880-1930. Montevideo, Planeta-Fundación MAPFRE, pp. 35-84.

"Caetano, G., Jacob, R. (1990). El nacimiento del terrismo. Montevideo: Ediciones de la Banda Oriental, tomo II.

" Cocchi, A., Frega, A., Nahum, B., Trochon, Y. (1994). Crisis política y recuperación económica. 1930-1958. Montevideo: Ediciones de la Banda Oriental.

" Cores, H. (1989). La lucha de los gremios solidarios (1947-1952). Montevideo: Ediciones de la Banda Oriental.

" (1970). Cuadernos de Marcha, 44.

"Cuadro, I. (2010). Partidos, elecciones y democracia política. AA.VV. Historia del Uruguay en el siglo XX. Montevideo: Ediciones de la Banda Oriental, pp. 317-357.

" D’Elía, G. (1982). El Uruguay neo-batllista, 1946-1958. Montevideo: Ediciones de la Banda Oriental.

"Demasi, C. (2001). 1968. Del Neobatllismo al Autoritarismo. Encuentros Uruguayos, 7, pp. 11-44.

" Díaz, H (coord.) (2019). Espionaje y revolución en el Río de la Plata. Los archivos secretos de una red diplomática de persecución al maximalismo (1918-1919). Buenos Aires: $\mathrm{CEHTI} /$ Imago Mundi.

"Duffau, N. (2019). Historia de la locura en Uruguay (1860-1911). Alienados, médicos y representaciones sobre la enfermedad mental. Montevideo: Universidad de la República.

"Duffau, N. y Rico, A. (2012). El Poder Judicial bajo la Dictadura. Montevideo: Ediciones del $\mathrm{CIEJ} /$ Facultad de Humanidades y Ciencias de la Educación.

"Dutrénit Bielous, S. (2006). El Uruguay del exilio. Montevideo: Trilce.

" Espeche, X. (2016). La paradoja uruguaya. Intelectuales, latinoamericanos y nación a mediados del siglo XX. Quilmes: Universidad Nacional de Quilmes.

"Fessler, D. (2015). El delito con rostro. Los comienzos de la identificación de delincuentes en Uruguay. Passagens. Revista internacional de historia política e cultura jurídica, 7 (1), pp.15-39.

" Frega, A. (1993). "Como el Uruguay no hay". Apuntes en torno al Estado en los años cincuenta y su crisis. Encuentros. Revista de Estudios Interdisciplinarios. 2, pp. 91-103.

" Frega, A., Maronna, M. y Trochón, Y. (1987). Baldomir y la restauración democrática (1938-1946). Montevideo: Ediciones de la Banda Oriental. 
" Frega, A., Maronna, M., Nahum, B. y Trochón, Y. (1993). El fin del Uruguay liberal. 19591973. Montevideo: Ediciones de la Banda Oriental.

" Frugoni, E. (1934). La revolución del machete. Buenos Aires: Claridad.

" García Ferrari, M. (2010). Ladrones conocidos/Sospechosos reservados. Identificación policial en Buenos Aires, 1880-1905. Buenos Aires: Prometeo.

" Gillespie, Ch. (1984). Desentrañando la crisis de la democracia uruguaya. Gillespie, Ch., Goodman, L., Rial, J. Winn, P. (comp.). Uruguay y la democracia. Montevideo: Ediciones de la Banda Oriental, tomo I, pp. 101-140.

" González Sierra, Y. (1989). Cronología histórica del movimiento sindical uruguayo (hechos, resoluciones y políticas y eventos sindicales). 1870-1984. Montevideo: CIEDUR.

" Kierszenbaum, L. (2012). Orígenes del orden represivo uruguayo: usos y percepciones de la violencia (1945-1968). Tesis doctoral, Instituto Sverdlin de Historia y Cultura de América Latina, Israel, Tel Aviv.

" "La era militar" (1973). Cuadernos de Marcha, 69.

" Leibner, G. (2011). Camaradas y compañeros. Una historia política y social de los comunistas del Uruguay. Montevideo: Trilce.

"López, S. (1985). Estado y Fuerzas Armadas en el Uruguay del siglo XX. Montevideo: Ediciones de la Banda Oriental.

" Lvovich, D. (2016). La Semana Trágica en clave transnacional. Influencias, repercusiones y circulaciones entre la Argentina, Brasil, Chile y Uruguay (1918-1919). Bertonha, J.F. y Bohoslavsky, E. (coord.). Circule por la derecha. Percepciones, redes y contactos entre las derechas sudamericanas, 1917-1973. Buenos Aires: Universidad Nacional de General Sarmiento.

" Marchesi, A. y Markarian, V. (2012). Cinco décadas de estudios sobre la crisis, la democracia y el autoritarismo en Uruguay. Contemporánea, 3, pp. 213-242.

" Martínez, V. (2013). Los rusos de San Javier. Montevideo: Ediciones de la Banda Oriental.

" Muñoz, P. (2014). La semana roja de Montevideo (I, II y III). Tierra y tempestad, 18, 19 y 20.

" Porrini, R. (1994a). Los derechos humanos durante el terrismo: vigencia y transgresión. 1933-1938. El Uruguay de los años treinta. Montevideo: Ediciones de la Banda Oriental, pp. $123-158$.

" Porrini, R. (1994b). Médicos e inmigración: una opción restrictiva en la década 19301940. Hoy es Historia, 61, pp. 15-29.

" Rama, G. (1987). La democracia en Uruguay. Buenos Aires: Grupo Editor Latinoamericano.

" Ramírez, G. (1988). El factor militar. Génesis, desarrollo y participación política. Montevideo: Arca.

" Real de Azúa, C. (1984). Uruguay, ¿una sociedad amortiguadora? Montevideo: Ediciones de la Banda Oriental.

" Real de Azúa, C. (1997). Ejército y política en el Uruguay [edición original de 1969]. Real de Azúa, C., Historia y política en el Uruguay. Montevideo: Cal y Canto.

" República Oriental del Uruguay (1889). Código Penal de la República Oriental del Uruguay. Montevideo: El Siglo llustrado.

" Rial, J. (1984). Partidos políticos, democracia y autoritarismo. Montevideo: CIESUEdiciones de la Banda Oriental, vols. I y II. 
" Rico, A. (1989). Del liberalismo democrático al liberalismo conservador. Montevideo: Facultad de Humanidades y Ciencias.

" Rico, A. (2003). Del orden político democrático al orden policial del Estado. Separata de Brecha. A 30 años del golpe de Estado (I), 6-6-2003, pp. 2, 3.

" Rico, A., coordinador. (2008). Investigación Histórica sobre la dictadura y el terrorismo de Estado en Uruguay. (1973-1985). Montevideo: CSIC, tomos I, II.

" Rilla, J. (2015). "Abrir bajo otro sol los ojos de mi hijo". Violencia, política e historiografía en Uruguay. Pasado Abierto, 2, pp. 218-241.

" Ruiz, E. (2010). Del viraje conservador al realineamiento internacional. 1933-1945. AA.VV. Historia del Uruguay en el siglo XX. Montevideo: Ediciones de la Banda Oriental, pp. 85121.

"Varela, G. (1988). De la república liberal al Estado militar. Montevideo: Nuevo Mundo.

"Victoria Rodríguez, J. (2008). Evolución histórica de la policía uruguaya. Montevideo: Byblos, tomo III.

"Zubillaga, C. (1997). Pan y trabajo. Organización sindical, estrategias de lucha y arbitraje estatal en Uruguay (1870-1905). Montevideo: Librería de la Facultad de Humanidades y Ciencias de la Educación. 